\title{
Hydrogen Storage and Delivery: The Carbon Dioxide - Formic Acid Couple
}

\author{
Gábor Laurenczy*
}

\begin{abstract}
Carbon dioxide and the carbonates, the available natural $\mathrm{C}_{1}$ sources, can be easily hydrogenated into formic acid and formates in water; the rate of this reduction strongly depends on the $\mathrm{pH}$ of the solution. This reaction is catalysed by ruthenium(II) pre-catalyst complexes with a large variety of water-soluble phosphine ligands; high conversions and turnover numbers have been realised. Although ruthenium(II) is predominant in these reactions, the iron(II) - tris[(2-diphenylphosphino)-ethyl]phosphine $\left(\mathrm{PP}_{3}\right)$ complex is also active, showing a new perspective to use abundant and inexpensive iron-based compounds in the $\mathrm{CO}_{2}$ reduction. In the catalytic hydrogenation cycles the in situ formed metal hydride complexes play a key role, their structures with several other intermediates have been proven by multinuclear NMR spectroscopy. In the other hand safe and convenient hydrogen storage and supply is the fundamental question for the further development of the hydrogen economy; and carbon dioxide has been recognised to be a viable $\mathrm{H}_{2}$ vector. Formic acid - containing 4.4 weight $\%$ of $\mathrm{H}_{2}$, that is $53 \mathrm{~g}$ hydrogen per litre - is suitable for $\mathrm{H}_{2}$ storage; we have shown that in aqueous solutions it can be selectively decomposed into $\mathrm{CO}$-free $(\mathrm{CO}<10 \mathrm{ppm}) \mathrm{CO}_{2}$ and $\mathrm{H}_{2}$. The reaction takes place under mild experimental conditions and it is able to generate high pressure $\mathrm{H}_{2}$ (up to 600 bar). The cleavage of $\mathrm{HCOOH}$ is catalysed by several hydrophilic Ru(I) phosphine complexes (meta-trisulfonated triphenylphosphine, $m$ TPPTS, being the most efficient one), either in homogeneous systems or as immobilised catalysts. We have also shown that the iron(II) - hydrido tris[(2-diphenylphosphino)ethyl]phosphine complex catalyses with an exceptionally high rate and efficiency (turnover frequency, TOF $=9425 \mathrm{~h}^{-1} \mathrm{~mol}^{-1}$; turnover number, $\mathrm{TON}=92400$ ) the formic acid cleavage, in environmentally friendly propylene carbonate solution, opening the way to use cheap, non-noble metal based catalysts for this reaction, too.
\end{abstract}

Keywords: $\mathrm{CO}_{2}$ reduction · Formic acid · High-pressure $\mathrm{H}_{2}$ generation · Hydrogen storage · Iron catalysis . Ruthenium catalyst

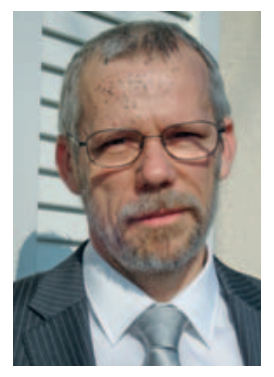

\section{Introduction}

Carbon dioxide, the abundant waste product of combustion reactions, is present with an increasing concentration in the atmosphere as a renewable $\mathrm{C}_{1}$ feedstock; limestone and magnesite are widely available on the Earth. ${ }^{[1]}$ The conversion of these non-toxic, green, cheap and safe reagents into useful organics (e.g. into formic acid)

${ }^{\star}$ Correspondence: Prof. G. Laurenczy

EPFL SB ISIC LCOM

Group of Catalysis for Energy and Environment (GCEE) BCH 2405

$\mathrm{CH}-1015$ Lausanne

Tel.: +41216939858

Fax: +41216939780

E-mail: Gabor.Laurenczy@epfl.ch

is a great challenge for chemistry, since carbon dioxide is a thermodynamically very stable $\left(\Delta H_{\mathrm{f}}^{\circ}=-393.5 \mathrm{~kJ} / \mathrm{mol}\right)$ and inert compound. So the reactions of $\mathrm{CO}_{2}$ often require harsh conditions, with catalysts and reactants having high energy content. Its utilisation therefore requires the identification of reaction pathways, the understanding and development of catalysts, and the investigation of energetic constraints. The first product of the stepwise reduction of $\mathrm{CO}_{2}$ with $\mathrm{H}_{2}$ is formic acid, but in the gas phase this reaction does not take place, ${ }^{[2]}$ as $\Delta \mathrm{G}^{\circ}{ }_{298}=+32.9 \mathrm{~kJ} / \mathrm{mol}$ (Eqn. (1)):

$$
\mathrm{CO}_{2(\mathrm{~g})}+\mathrm{H}_{2(\mathrm{~g})} \rightarrow \mathrm{HCOOH}_{(\mathrm{g})}
$$

Dissolution of the gases decreases the entropy term, in aqueous solution this reaction becomes slightly exergonic with $\Delta \mathrm{G}^{\circ}{ }_{298}=-4 \mathrm{~kJ} / \mathrm{mol}$ (Eqn. (2)):

$$
\mathrm{CO}_{2(\mathrm{aq})}+\mathrm{H}_{2(\mathrm{aq})} \rightarrow \mathrm{HCOOH}_{(\mathrm{aq})}
$$

Addition of a base improves the enthalpy of the reaction $\left(\Delta \mathrm{G}^{\circ}{ }_{298}=-35.4 \mathrm{~kJ} /\right.$ $\mathrm{mol} ; \Delta \mathrm{H}^{\circ}{ }_{298}=-59.8 \mathrm{~kJ} / \mathrm{mol} ; \Delta \mathrm{S}^{\circ}{ }_{298}=-81 \mathrm{~J} /$ $\mathrm{mol} / \mathrm{K})$, making this reaction largely accessible (Eqn. (3)):

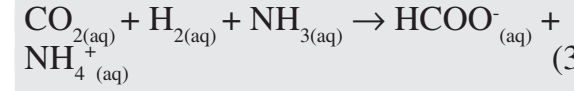

Numerous platinum group metal complexes catalyse the hydrogenation of $\mathrm{CO}$ to formic acid under both sub- and supercritical conditions, in organic solvents, in water or in aqueous biphasic systems (Fig. 1). In the synthesis of dimethyl-formate from $\mathrm{CO}_{2}, \mathrm{H}_{2}$ and trimethylamine Jessop and co-workers achieved turnover frequencies (TOF) up to $7200 \mathrm{~h}^{-1}$ using $\left[\mathrm{RuCl}_{2}\left(\mathrm{PMe}_{3}\right)_{4}\right]$ as catalyst in $\mathrm{scCO}_{2}$ as solvent, ${ }^{[3]}$ while Baiker et al..$^{[4]}$ used a $\left[\mathrm{RuCl}_{2}(\mathrm{dppe})_{2}\right]$ catalyst $\left[\right.$ dppe $=\mathrm{Ph}_{2} \mathrm{P}\left(\mathrm{CH}_{2}\right)_{2} \mathrm{PPh}_{2}$ ] for the hydrogenation of $\mathrm{CO}_{2}$ in the presence of dimethylamine with an extremely high TOF of $360000 \mathrm{~h}^{-1}$. So far, the highest TON reported for $\mathrm{CO}_{2}$ hydrogenation, 3.5 million, was published by Nozaki who used a pincer-type Ir(III)-catalyst for the reaction. ${ }^{[5]}$ Although an important goal in catalysis is to replace noble metal-based catalysts with cheap, abundant, non-precious metalbased systems, there are only two examples for the homogeneous catalysed reduction of carbon dioxide: Evans and Newell described a catalytic system with very low activity $\left(\mathrm{TOF}=0.06 \mathrm{~h}^{-1}\right)$ and Jessop et al. reported a TON of 113 using $\mathrm{Fe}(\mathrm{OAc})_{2}$ and 1,2-bis(dicyclohexyl)phosphinoeth- 


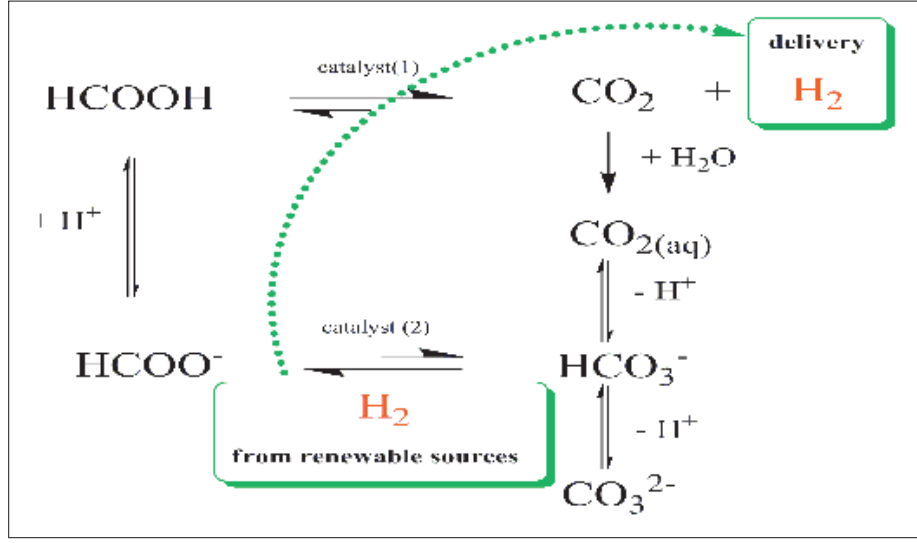

Fig. 1. The carbon dioxide hydrogenation-formic acid decomposition cycle.

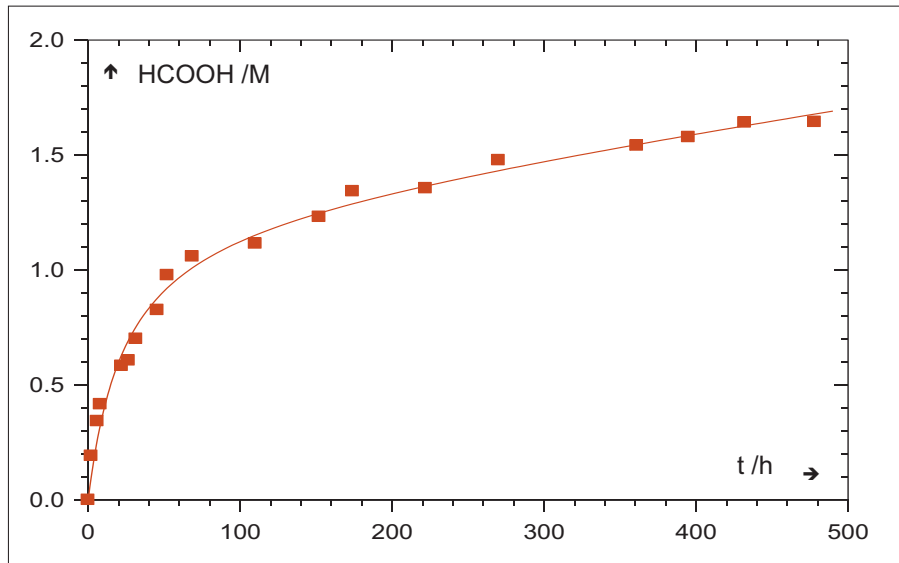

Fig. 2. Typical, characteristic concentration/time profile of $\mathrm{CO}_{2} / \mathrm{CaCO}_{3}$ reduction into $\mathrm{HCOO}^{-}$at $323 \mathrm{~K}$, followed in situ by ${ }^{1} \mathrm{H}$ and ${ }^{13} \mathrm{C}$ NMR. Initial conditions: $\mathrm{CaCO}$ solid $=200 \mathrm{mg}$ (in 2.0 $\mathrm{ml}$ water), $\mathrm{P}\left(\mathrm{CO}_{2}\right)=$ 30 bar, $\mathrm{P}\left(\mathrm{H}_{2}\right)=20$ bar, shaking: $300 \mathrm{~min}^{-1}$, initial TOF $=37 \mathrm{~h}^{-1}$, TON $=626$.

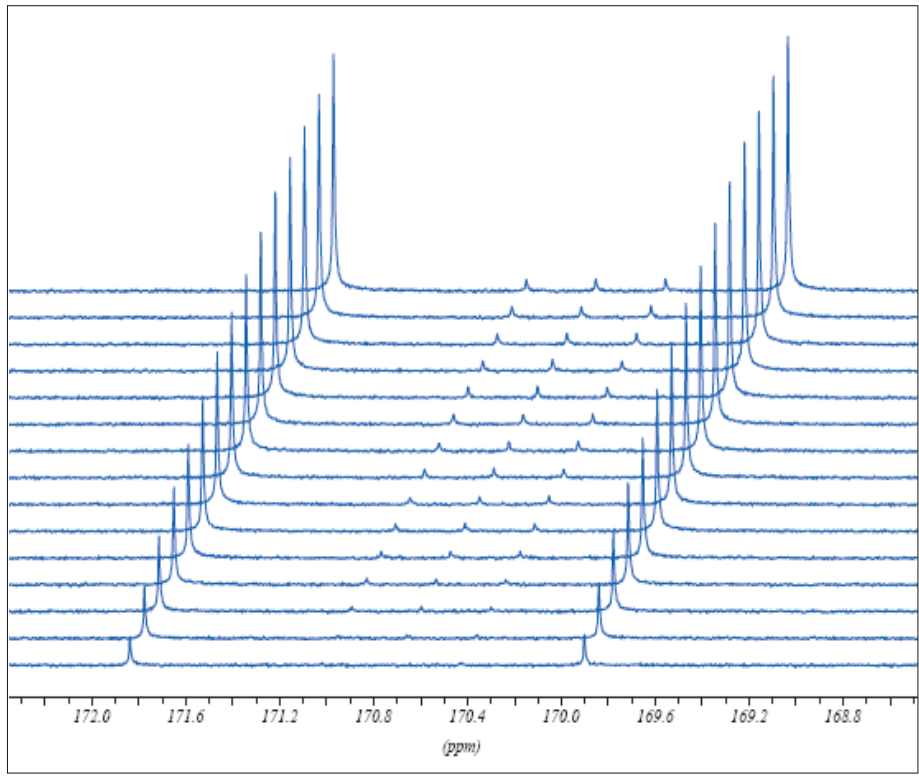

Fig. 3. Evolution of the ${ }^{13} \mathrm{C}$ NMR signals of the formate $\left[\mathrm{H}^{13} \mathrm{COO}\right]^{-}, \delta=170.9$ ppm, ${ }^{1} \mathrm{~J}_{\mathrm{CH}}=194 \mathrm{~Hz}$ (and [D $\left.{ }^{13} \mathrm{COO}\right]^{-}, \delta=$ $170.7 \mathrm{ppm},{ }^{1} \mathrm{~J}_{\mathrm{CD}}=32$ $\mathrm{Hz}$ ) in the bicarbonate hydrogenation reaction, followed in situ at $\mathrm{T}=303 \mathrm{~K}$. The time delay between spectra 1 hour, initial conditions: $\left[\mathrm{NaH}^{13} \mathrm{CO}_{3}\right]=$ $0.15 \mathrm{M}, \mathrm{C}_{\text {cat }}=0.0012$ $\mathrm{M}, \mathrm{p}\left(\mathrm{H}_{2}\right)=100$ bar.

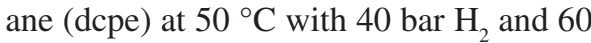
bar $\mathrm{CO}_{2} \cdot{ }^{[6]}$

On the other hand, hydrogen is one of the promising candidates as an energy carrier to replace traditional fossil fuels both for environmental and economic reasons. Hydrogen has the advantage of being non-toxic and forms only water when it burns. Combined with fuel cell technology, very efficient energy conversion can be achieved. [7] However, its storage remains a challenge: Conventional hydrogen storage methods, like high-pressure gas bottles and cryogenic liquid containers, have weight and safety issues. Therefore a variety of new materials have been developed, such as metal hydrides, metal-organic frameworks, carbon nanostructures, small inorganic and organic 'hydrides'. These strategies have their own technical and cost problems, and so solutions to overcome them are currently an active area of research. Formic acid is among the potential candidates, among the small organic molecules, for $\mathrm{H}_{2}$ storage and delivery. $\mathrm{HCOOH}$ has a flash point of $+69^{\circ} \mathrm{C}$, much higher than that of the gasoline $\left(-40^{\circ} \mathrm{C}\right)$ or methanol $\left(+12^{\circ} \mathrm{C}\right)$. Since 2006 several potentially applicable catalysts have been developed for the formic acid-based hydrogen generation. We have found that $\mathrm{Ru}(\mathrm{II})$ with the water-soluble $m$-trisulfonated triphenylphosphine ( $m$ TPPTS) ligand can selectively decompose $\mathrm{HCOOH}$ into carbon monoxide-free hydrogen and carbon dioxide in a very wide pressure range. ${ }^{[8]}$ Beller et al. ${ }^{[9]}$ established that the ruthenium and iron phosphine-arene complexes can selectively produce $\mathrm{H}_{2}$ and $\mathrm{CO}_{2}$ from a $\mathrm{HCOOH}$-amine azeotrope. Later Wills, Himeda and Fukuzumi proposed several Ir, $\mathrm{Rh}$ and $\mathrm{Ru}$ complexes for selective hydrogen generation from formic acid. ${ }^{[10]}$

\section{Results and Discussion}

To hydrogenate carbon dioxide, the transformation of hydrogen storage and delivery cycle into a $\mathrm{CO}_{2}$ neutral procedure, an efficient $\mathrm{CO}_{2}$ reduction method is necessary. Our results show ${ }^{[11]}$ that carbon dioxide and carbonates can be hydrogenated catalytically in water, using even $\mathrm{CaCO}_{3}$ for thermodynamic sink to the reaction (Fig. 2).

A large number of $\mathrm{Ru}(\mathrm{II})$ phosphine complexes have been found catalytically active for $\mathrm{CO}_{2}$ hydrogenation. High reaction rates, turnover numbers and turnover frequencies are necessary for efficient reduction. On the other hand, to detect intermediates, to obtain detailed mechanistic information, slow reactions are often helpful. $\left[\mathrm{RuCl}_{2}(\mathrm{PTA})\left([9] \mathrm{aneS}_{3}\right)\right]$ (where PTA $=$ 1,3,5-triaza-7-phosphadamantane, and [9] aneS3 = 1,4,7-trithiacyclononane) also catalyses the hydrogenation of $\mathrm{CO}_{2}$, bicarbonate and carbonate ions to formic acid/formate ion in aqueous solution under mild conditions. ${ }^{[11 \mathrm{k}]}$ While the activity of this catalyst is low, the formation of an intermediate involving coordination of both hydride and bicarbonate to the ruthenium centre has been unambiguously established by ${ }^{1} \mathrm{H},{ }^{31} \mathrm{P}$ and ${ }^{13} \mathrm{C}$ NMR spectroscopy, the $\left[\mathrm{Ru}(\mathrm{H})\left(\mathrm{CO}_{3} \mathrm{H}\right)(\mathrm{PTA})\left([9] \mathrm{aneS}_{3}\right)\right]$ complex has been characterised in situ in the reaction medium (Fig. 3). The reduction of $\mathrm{CO}_{2}$ takes place via this bicarbonate species and the rate-determining step appears to be the intramolecular hydride transfer from the metal to the coordinated bicarbonate/ $\mathrm{CO}_{2}$. No other products were detected during the catalytic runs beside the deuterated ${ }^{[12]}$ DCOO$^{-}$.

Despite of the fact that the platinum group metals are the best catalysts today for carbon dioxide/bicarbonate hydrogenation, we have shown recently that the iron(II)-tris[(2-diphenylphosphino)-ethyl] phosphine $\left(\mathrm{PP}_{3}\right)$ complex is also active, opening a new perspective to use abundant 


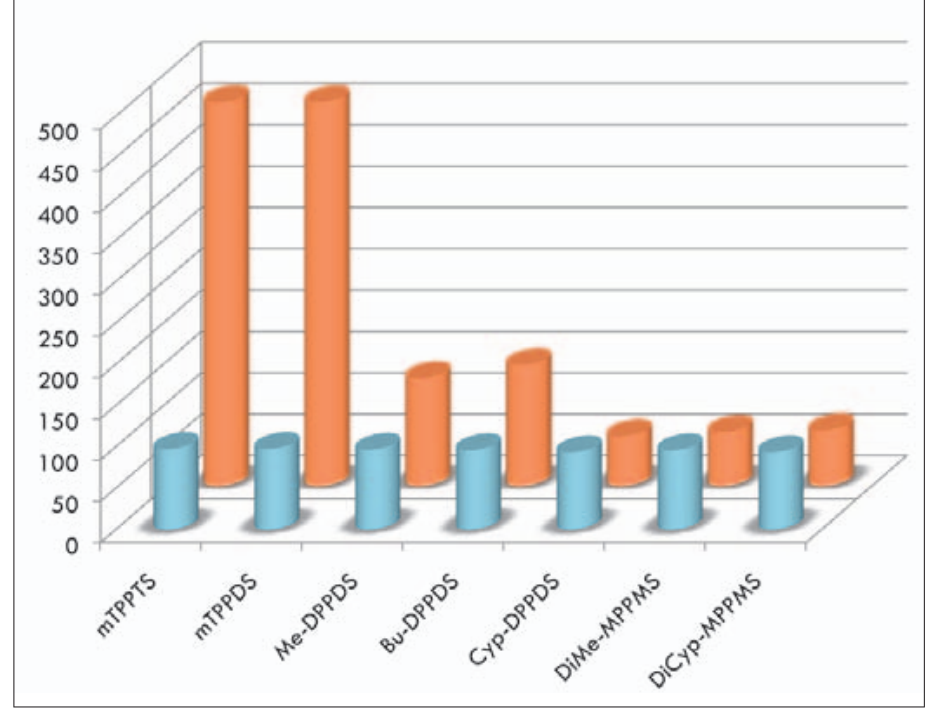

Fig. 4. Decomposition of $10 \mathrm{mmol} \mathrm{HCOOH}$ into $\mathrm{H}_{2}$ and $\mathrm{CO}_{2}$, catalysed by $22 \mu \mathrm{mol} \mathrm{Ru(II)}$ with 2 equiv. phosphine in $2.5 \mathrm{ml} \mathrm{H}_{2} \mathrm{O} / \mathrm{D}_{2} \mathrm{O}(1: 1), 90^{\circ} \mathrm{C}$. Grey colour: conversion (\%), brown colour: turnover frequency (TOF in $\left.\mathrm{h}^{-1}\right)$. Phosphines: m-trisulfonato triphenylphosphine (mTPPTS), di $(m-$ sulfonato)triphenyl phosphine (mTPPDS), methyl-di( $m$-sulfonato-phenyl) phosphine (MeDPPS), butyl-di( $m$-sulfonato-phenyl)phosphine (BuDPPS), cyclopentyl-di( $m$-sulfonato-phenyl)phosphine (CypDPPS), dimethyl-( $m$ sulfonato-phenyl)phosphine (DiMeMPPMS), and dicyclopentyl-( $m$-sulfonato-phenyl)phosphine (DiCypMPPMS)

and inexpensive iron-based compounds in the $\mathrm{CO}_{2}$ reduction. ${ }^{[13]}$

The selective homogeneous catalytic decomposition of formic acid in aqueous solution can be carried out using hydrophilic ruthenium-based catalysts, generated from the highly water-soluble ligand meta-trisulfonated triphenylphosphine and $\mathrm{RuCl}_{3}{ }^{[8 \mathrm{8}]}$ The formic acid splitting reaction takes place under mild experimental conditions, in a wide range of temperature, and at a controllable rate. On the basis of this catalytic system, $\mathrm{HCOOH}$ can be used as a viable hydrogen storage material. It has also been shown ${ }^{[8 \mathrm{e}]}$ that a large number of the water-soluble sulfonato aryl- and aryl-/ alkylphosphine ligands can be applied successfully in aqueous-phase ruthenium(II)catalysed formic acid decomposition into hydrogen and carbon dioxide with a very high yield, between $95 \%$ and $100 \%$.

The structures, the electronic and steric properties of these phosphine ligands influences the rate of hydrogen generation from $\mathrm{HCOOH}$. The very good activity, observed with $m$ TPPTS and $m$ TPPDS, is probably due to a compromise between steric effects and ligand basicities, but notably the high stability and high solubility of these ligands (Fig. 4).

\section{Conclusions}

Several catalysts have been developed for the homogeneous catalytic hydrogenation of carbon dioxide, bicarbonate and carbonate in water since aqueous systems are well suited for this process. No additives are needed for an efficient reduction, the $\mathrm{pH}$ can be regulated through the $\mathrm{CO}_{2} /$ $\mathrm{HCO}_{3}^{-} / \mathrm{CO}_{3}^{2-}$ buffer by varying the $\mathrm{CO}_{2}^{2}$ pressure. Slightly acidic/neutral conditions are beneficial for the reduction as a compromise between increased concentration of the catalytically active metal hydrides and the highest available concentration of $\left[\mathrm{HCO}_{3}^{-}\right]$. The main role of amines used in earlier studies is to shift the $\mathrm{pH}$ in favour of the formation of bicarbonate.

Homogeneous catalytic systems based on water-soluble ruthenium(II)phosphine catalysts selectively decompose $\mathrm{HCOOH}$ into $\mathrm{H}_{2}$ and $\mathrm{CO}_{2}$ in aqueous solution. The catalytically active hydrido complexes are formed in situ from $\mathrm{Ru}(\mathrm{II})$, or $\mathrm{Ru}(\mathrm{III})$ with the water-soluble phosphine TPPTS as co-catalyst. This reaction provides an efficient in situ method for hydrogen production that operates over a wide range of pressures, under mild conditions, and at a controllable rate. Multinuclear NMR spectroscopy allowed several intermediates to be identified, which led to a tentative reaction mechanism consisting of two competitive catalytic cycles, involving a monohydrido ruthenium complex [RuH(TPPTS $\left.)_{2}\left(\mathrm{H}_{2} \mathrm{O}\right)_{3}\right]^{+}$ as a common intermediate. On the basis of these results one can envisage the practical use of carbon dioxide as hydrogen vector. Previous limitations to the application of formic acid as hydrogen storage material, notably catalyst deactivation and the formation of side products, have been overcome.[14]

In propylene carbonate solution, with an iron(II)-based catalyst system, consisting of $\mathrm{Fe}\left(\mathrm{BF}_{4}\right)_{2} \cdot 6 \mathrm{H}_{2} \mathrm{O}$ and tris $[(2-$ diphenylphosphino)ethyl]phosphine $\left(\mathrm{P}\left(\mathrm{CH}_{2} \mathrm{CH}_{2} \mathrm{PPh}_{2}\right)_{3}, \quad \mathrm{PP}_{3}\right)$, a remarkably high activity, with turnover frequencies up to $9425 \mathrm{~h}^{-1}$ and turnover numbers of more than 92,000 , was achieved.[15]

\section{Experimental}

\subsection{Carbon Dioxide Reduction}

$\mathrm{D}_{2} \mathrm{O}(99.9 \%), \mathrm{Na}_{2}{ }^{13} \mathrm{CO}_{3}$ and $\mathrm{NaH}^{13} \mathrm{CO}$ $\left(99 \%\right.$ enriched in ${ }^{13} \mathrm{C}$ ) were purchased from Cambridge Isotope Laboratories. $\mathrm{Na}_{2} \mathrm{CO}_{3}$ and $\mathrm{NaHCO}_{3}$ were obtained from Fluka. $\mathrm{H}_{2}$ and $\mathrm{CO}_{2}$ were acquired from Carbagas-CH. All materials were used as received. The reactions were carried out in high pressure sapphire NMR tubes (pressure $<120$ bar) and were followed by NMR spectroscopy. ${ }^{1} \mathrm{H},{ }^{13} \mathrm{C}$ and ${ }^{31} \mathrm{P}$ NMR spectra were recorded on Bruker DRX 400 NMR spectrometer. TSPSA and phosphoric acid were used ${ }^{[16]}$ as references for the ${ }^{1} \mathrm{H},{ }^{13} \mathrm{C}$ and ${ }^{31} \mathrm{P}$ NMR measurements, respectively. The spectra were fitted with WINNMR and NMRICMA/MATLAB programs (non-linear least square fit to determine the spectral parameters). The samples were pressurised with $\mathrm{H}_{2}$ up to 100 bar in $10 \mathrm{~mm}$ high pressure sapphire NMR tubes. The tube was thermostated to the desired temperature in the NMR spectrometer and the reactions were followed by multinuclear NMR technique. The concentrations of $\mathrm{HCO}_{2}^{-}$, $\mathrm{CO}_{3}{ }^{2-} / \mathrm{HCO}_{3}^{-}$and $\mathrm{CO}_{2}$ were determined from integration of the corresponding ${ }^{1} \mathrm{H}$ and ${ }^{13} \mathrm{C}$ NMR signals. The initial rates and turnover frequencies ( $\mathrm{TOF}=\mathrm{mol}$ formate/ mol catalyst $/ \mathrm{h}^{-1}$ ) were calculated by nonlinear least squares fits of the experimental data from the initial part of the reactions. The reaction intermediates were identified by multinuclear NMR spectroscopy.

\subsection{Hydrogen Generation}

Kinetic experiments were performed in $10 \mathrm{~mm}$ high-pressure sapphire NMR tubes. In a typical experiment, the ruthenium pre-catalyst was dissolved in a formic acid/sodium formate $(9: 1,4 \mathrm{M})$ aqueous solution $\left(2.5 \mathrm{ml}, 1: 1 \mathrm{D} \mathrm{O} / \mathrm{H}_{2} \mathrm{O}\right)$ containing $m$ TPPTS or other ligand. The tube was then thermostated at $90{ }^{\circ} \mathrm{C}$ (or to the desired temperature), with an electric heating jacket or directly in the spectrometer. The reaction was followed by monitoring the pressure as a function of time with a pressure transducer connected to the tube via a high-pressure capillary, with a home-made LabView 8.2 program with a NI USB 6008 interface, and by ${ }^{1} \mathrm{H}$ or ${ }^{13} \mathrm{C}$ NMR spectroscopy. Conversions were determined by in- 
tegration of the formic acid/formate peak relative to that of water or to an external standard. Recycling of the catalyst was performed by cooling the sapphire tube to room temperature, depressurisation and addition of formic acid.

\section{Acknowledgements}

EPFL and the Swiss National Science Foundation are thanked for financial support.

Received: July 14, 2011

[1] 'Carbon dioxide recovery and utilization', Ed. M. Aresta, Dordrecht, Kluwer Academic Publishers, 2010.

[2] P. G. Jessop, T. Ikarya, R. Noyori, Chem. Rev. 1995, 95, 259.

[3] P. G. Jessop, T. Ikarya, R. Noyori, Nature 1994, 368, 231.

[4] O. Kröcher, R. A. Köppel, A. Baiker, J. Chem. Soc., Chem. Commun. 1997, 453.

[5] R. Tanaka, M. Yamashita, K. Nozaki, J. Am. Chem. Soc. 2009, 131, 14168.

[6] a) G. O. Evans, C. J. Newell, Inorg. Chim. Acta 1978, 31, L387; b) C.-C. Tai, T. Chang, B. Roller, P. G. Jessop, Inorg. Chem. 2003, 42, 7340 .

[7] a) L. Schlapbach, A. Züttel, Nature, 2001 414,353 ; b) B. Sorensen, 'Hydrogen and fuel cells, emerging technologies and applications', Elsevier, Amsterdam, 2005, p. 83; c) 'Handbook of Fuel Cells', Eds. W. Vielstich, A. Lamm, H. A. Gasteiger, Wiley, Chichester, 2003, Vol. 3, p. 79

[8] a) C. Fellay, P. J. Dyson, G. Laurenczy, EP 1918247, 2006; b) C. Fellay, P. J. Dyson, G. Laurenczy, Angew. Chem. Int. Ed. 2008, 47,
3966; c) C. Fellay, Ning Yan, P. J. Dyson, G. Laurenczy, Chem. Eur. J. 2009, 15, 3752; d) W. Gan, P. J. Dyson, G. Laurenczy, React. Kin. Catal. Letters 2009, 98, 205; e) W. Gan, C. Fellay, P. J. Dyson, G. Laurenczy, J. Coord. Chem. 2010, 63, 2685; f) A. Boddien, F. Gärtner, D. Mellmann, P. Sponholz, H. Junge, G. Laurenczy, M. Beller, Chimia, 2011, 65, 214.

[9] a) B. Loges, A. Boddien, H. Junge, M. Beller, Angew. Chem. Int. Ed. 2008, 47, 3962; b) A. Boddien, B. Loges, H. Junge, M. Beller, ChemSusChem 2008, 1, 751; c) H. Junge, A. Boddien, F. Capitta, B. Loges, J. R. Noyes, S. Gladiali, M. Beller, Tetrahedron Lett. 2009, 50, 1603; d) B. Loges, A. Boddien, H. Junge, J. R. Noyes, W. Baumann, M. Beller, Chem. Commun. 2009, 4185; e) A. Boddien, B. Loges, H. Junge, F. Gartner, J. R. Noyes, M. Beller, Adv. Synth. Catal. 2009, 351, 2517; f) A. Boddien, B. Loges, F. Gartner, C. Torborg, K. Fumino, H. Junge, R. Ludwig, M. Beller, J. Am. Chem. Soc. 2010, 132, 8924; g) A. Boddien, F. Gartner, R. Jackstell, H. Junge, A. Spannenberg, W. Baumann, R. Ludwig, M. Beller, Angew. Chem. Int. Ed. 2010, 49, 8993.

[10] a) D. J. Morris, G. J. Clarkson, M. Wills, Organometallics, 2009, 28, 4133; b) Y. Himeda, Green Chem. 2009, 11, 2018; c) S. Fukuzumi, T. Kobayashi, T. Suenobu, ChemSusChem, 2008, 1, 827; d) S. Fukuzumi, T. Kobayashi, T. Suenobu, J. Am. Chem. Soc. 2010, 132, 1496.

[11] a) F. Joó, G. Laurenczy, L. Nádasdi, J. Elek, Chem. Comm. 1999, 971; b) G. Laurenczy, F. Joó, L. Nádasdi, High Pressure Research 2000, 18, 251; c) F. Joó, G. Laurenczy, P. Karády, J. Elek, L. Nádasdi, R. Roulet, Appl. Organomet. Chem. 2000, 14, 857; d) G. Laurenczy, F. Joó, L. Nádasdi, Inorg. Chem. 2000, 39, 5083; e) F. Joó, J. Kovács, A. Cs. Bényei, L. Nádasdi, G. Laurenczy, Chem. Eur. J. 2001, 7, 193; f) A.
Ohlin, G. Laurenczy, High Pressure Research 2003, 23, 239; g) Á. Kathó, Zs. Opre, G. Laurenczy, F. Joó, J. Mol. Catal. A: Chemical 2003, 204-205, 143; h) J. Elek, L. Nádasdi, G. Papp, G. Laurenczy, F. Joó, Appl, Catal. A: General 2003, 255, 59; i) H. Horváth, G. Laurenczy, Á. Kathó, J. Organomet. Chem. 2004, 689, 1036; j) T. Geldbach, G. Laurenczy, R. Scopelliti, P. Dyson, Organometallics 2006, 25, 733; k) G. Laurenczy, S. Jedner, E. Alessio, P. J. Dyson, Inorg. Chem. Commun. 2007, 10, 558; 1) A. Urakawa, F. Jutz, G. Laurenczy, A. Baiker, Chem. Eur. J. 2007, 13, 3886; m) S. S. Bosquain, A. Dorcier, P. J. Dyson, M. Erlandsson, L. Gonsalvi, G. Laurenczy, M. Peruzzini, Appl. Organomet. Chem. 2007, 21, 947; n) M. Erlandsson, V. R. Landaeta, L. Gonsalvi, M. Peruzzini, A. D. Phillips, P. J. Dyson, G. Laurenczy, Eur. J. Inorg. Chem. 2008, 620 ; o) C. Federsel, R, Jackstell, A. Boddien, G. Laurenczy, M. Beller, ChemSusChem 2010, 3, 1048.

[12] G. Kovács, L. Nádasdi, G. Laurenczy, F. Joó, Green Chem. 2003, 5, 213.

[13] C. Federsel, A. Boddien, R. Jackstell, R. Jennerjahn, P. J. Dyson, R. Scopelliti, G. Laurenczy, M. Beller, Angew. Chem. Int. Ed. 2010, 49, 9777.

[14] a) F. Joó, ChemSusChem 2008, 1, 805; b) S. Enthaler, ChemSusChem, 2008, 1, 801.

[15] A. Boddien, D. Mellmann, F. Gärtner, R. Jackstell, H. Junge, P. J. Dyson, G. Laurenczy, R. Ludwig, M. Beller, Science, 2011, accepted for publication.

[16] G. Laurenczy, A. E. Merbach, Chem. Comm. 1993, 187. 